\title{
Determining the degree of kinship of sarlik yaks bred in the mountainous regions of the Kabardino-Balkarian Republic by blood groups
}

\author{
Lyudmila Sabanchieva ${ }^{1}$, Kristina Kanukova ${ }^{1}$, Ismail Gazaev ${ }^{1}$, Murat Gubzhokov ${ }^{2}$, and \\ Zalina Bogotova ${ }^{1,2}$ \\ ${ }^{1}$ Federal State Budgetary Research Institution "Federal Research Center "Kabardino-Balkarian \\ Research Center of the Russian Academy of Sciences", Balkarova Str., 2, 360002 Nalchik, Russia \\ ${ }^{2}$ Institute of Agriculture - branch of the Kabardino-Balkarian Research Center of the Russian \\ Academy of Sciences, Kirova Str., 224, 360004 Nalchik, Russia \\ ${ }^{1,2}$ Federal State Budgetary Educational Institution of Higher Education "H.M. Berbekov Kabardino- \\ Balkarian State University”, Chernyshevsky Str., 173, 360004 Nalchik, Russia
}

\begin{abstract}
The formation of immunogenetics as a science was the result of numerous studies on the study of blood groups and other polymorphic systems, the results of which are successfully applied both in animal husbandry and in animal breeding. Modern biotechnological methods used to analyze blood groups enable us to determine the true origin of animals. To determine the correctness of the breeding processes occurring in the breed, the antigenic composition of blood groups, which are also used to study the reliability of origin, needs to be studied. The results obtained make it possible to analyze genetic similarity, determine the level of polymorphism and the nature of structural changes in the result of breeding work. Also, by analyzing the distribution of the frequency of occurrence of antigens, it is possible to determine the genetic distances and genetic similarity of breeds and lines among themselves [1].
\end{abstract}

\section{Introduction}

Currently, the control of the origin of individual lines, breeds and whole herds by means of immunogenetic analysis to determine animals for breeding purposes is very relevant and contributes to an increase in the efficiency of selection and breeding in animal husbandry $[1,2,3]$.

To confirm the authenticity of the origin of an individual, this method is more optimal, due to its information content, development and accessibility. The principle of immunogenetic analysis is to determine blood groups in parental forms and offspring and to analyze their correspondence, which makes it possible to solve the following issues:

- establishing the origin of the offspring by sire and by dam (reliability of origin);

- identification of genetic abnormalities;

- control of genetic safety;

- assessment of the prospects for animal genetic resources. 
A scientific article by Koltsov D.N., Romanov Yu.D., Gontov M.E. presents the results of the works of such scientists as Rendel J. et al. on the obtained interbreed discrepancies in the blood groups of cattle. The determining factors contributing to the establishment of the degree of kinship in livestock breeding are the results of studies of blood groups, establishing the origin of both breeds and individual groups of animals and their relationships. According to the laboratory research carried out by I. Matoushek, it was revealed that several breeds took part in the formation of the Czech red-and-white cattle breed [4].

Data from numerous studies show the relationship of blood groups with the productivity of certain traits of animals that play an important role in animal husbandry. Thus, for example, the scientific works of I.R. Giller, according to the definition of the blood group of a cow of the Trostyanets breeding plant named Vorotka, reflect this theory. Later it was found that some representatives of her offspring inherited high milk fat and alleles from the $\mathrm{B}$ system $\left(\mathrm{O}, \mathrm{I}, \mathrm{T}, \mathrm{G}^{\prime}, \mathrm{K}^{\prime}\right)$, while others, without alleles from this system, did not differ in significant indicators of fat milk. Thus, the establishment of genetic similarity between parents and offspring in terms of the frequency of occurrence of blood groups of parents with offspring has become the most important, and the results are very valuable in the management of breeding animals [5].

Recently, genetic examination has become very relevant. The expediency of this analysis lies in the possibility of eliminating errors when taking into account data on the origin of purebred animals arising from some features of the technology of livestock breeding, where the percentage of error is $15-20 \%$. And sometimes the number of records with incorrect data can reach up to $50 \%$.

On the basis of the order of the Ministry of Agriculture of Russia, immunogenetic laboratories are organized in animal breeding areas, the work of which consists in the correctness and accuracy of testing to breed significant purebred livestock. The factors that allow for controlling the reliability of the origin of animals are:

- codominance of inheritance of antigenic factors and their invariability during ontogenesis;

- numerous combinations of blood groups [6,7].

To obtain objective data on the origin, it is necessary to take blood from the alleged parents and offspring. The presence of identical antigens in animals indicates their relationship, and antigens found in the offspring, which are not included in the genetic structure of the parents, exclude the fact of their relationship. The reliability of the data can be seen in (Table 1) [8].

Table 1. Differences in determining the degree of kinship.

\begin{tabular}{|c|c|c|c|}
\hline & & Calf & Result \\
\hline Bull & $\begin{array}{c}\mathrm{I}_{1} \mathrm{~A}_{2}^{\prime} \mathrm{P}_{2}^{\prime} \mathrm{R}_{2} \mathrm{~F} \\
\mathrm{Z}\end{array}$ & \multirow[t]{2}{*}{$\begin{array}{c}\mathrm{G}_{2} \mathrm{I}_{2} \mathrm{~A}_{2}^{\prime} \\
\mathrm{P}^{\prime}{ }_{2} \mathrm{O}^{\prime}\end{array}$} & \multirow[t]{2}{*}{$\begin{array}{l}\text { Kinship is } \\
\text { confirmed }\end{array}$} \\
\hline Cow & $\begin{array}{c}\mathrm{G}_{2} \mathrm{I}_{2} \mathrm{Y}_{2} \mathrm{E}_{3}^{\prime} \mathrm{O}^{\prime} \\
\mathrm{U}^{\prime}, \mathrm{H}\end{array}$ & & \\
\hline Bull & $\begin{array}{c}\mathrm{I}_{1} \mathrm{~A}_{2}^{\prime} \mathrm{P}_{2}^{\prime} \mathrm{R}_{2} \mathrm{~F} \\
\mathrm{Z} \\
\end{array}$ & \multirow{2}{*}{$\begin{array}{c}\mathrm{G}_{2} \mathrm{~TB}^{\prime} \\
\mathrm{D}^{\prime} \mathrm{Q}^{\prime} \mathrm{H}^{\prime \prime} \\
\mathrm{Z}\end{array}$} & \multirow[t]{2}{*}{$\begin{array}{l}\text { Kinship is } \\
\text { not confirme }\end{array}$} \\
\hline Cow & $\begin{array}{c}\mathrm{G}_{2} \mathrm{I}_{2} \mathrm{Y}_{2} \mathrm{E}_{3}^{\prime} \\
\mathrm{O}^{\prime} \mathrm{U}^{\prime} \mathrm{H}\end{array}$ & & \\
\hline
\end{tabular}

Thus, an immunogenetic analysis of the blood of cattle in order to establish the kinship is relevant and expedient, since it eliminates errors in the study and accounting of the reliability of the origin of breeding animals caused by objective and subjective reasons. 


\section{Methods and Materials}

The object of research were sarlik yaks bred in the "Selskie dary" pedigree breeding unit. Determining the analysis of blood cells for erythrocyte antigens and their relationship with economically useful traits allows you to effectively manage the genetic structure of the livestock.

Group erythrocyte antigens were determined according to the rules of genetic examination of cattle breeding material (Federal State Research Institution Rossinformagrotech, 2003. - 48 p.) in the laboratory of molecular selection and biotechnology of Kabardino-Balkarian Research Center of the Russian Academy of Sciences using 40 standard reagents 7 genetic systems produced by "Samarplem" JSC, which made it possible to determine the frequency of occurrence of blood group alleles in sarlik yaks and confirmation of the truth of the origin (Table 2, Figure 1,2,3) [8].

Table 2. List of standard reagents used.

\begin{tabular}{|c|c|}
\hline Systems & Antigens \\
\hline EAA & $\mathrm{A}_{1} \mathrm{~A}_{2}$ \\
\hline EAB & $\mathrm{G}_{2}, \mathrm{G}_{3}, \mathrm{I}_{1}, \mathrm{I}_{2}, \mathrm{P}_{2}, \mathrm{O}_{3}, \mathrm{O}_{4}, \mathrm{~A}_{2}^{\prime}, \mathrm{T} \mathrm{B}^{\prime} \mathrm{D}^{\prime} \mathrm{Q}^{\prime} \mathrm{Y}_{2} \mathrm{Y}_{2}^{\prime} \mathrm{E}_{3}^{\prime} \mathrm{G}^{\prime} \mathrm{O}^{\prime} \mathrm{P}_{2}^{\prime} \mathrm{T}_{1}$ \\
\hline EAC & $\mathrm{C}_{1} \mathrm{C}^{\prime} \mathrm{X}_{1} \mathrm{X}_{2} \mathrm{R}_{1} \mathrm{R}_{2} \mathrm{~W} \mathrm{~L}^{\prime}$ \\
\hline EAF & $\mathrm{F} \mathrm{V}$ \\
\hline EAS & $\mathrm{S}_{1} \mathrm{~S}_{2} \mathrm{U} \mathrm{U}^{\prime} \mathrm{U}^{\prime \prime} \mathrm{H} \mathrm{H}^{\prime} \mathrm{H}^{\prime \prime}$ \\
\hline EAZ & $\mathrm{Z}$ \\
\hline EAL & $\mathrm{L}$. \\
\hline
\end{tabular}

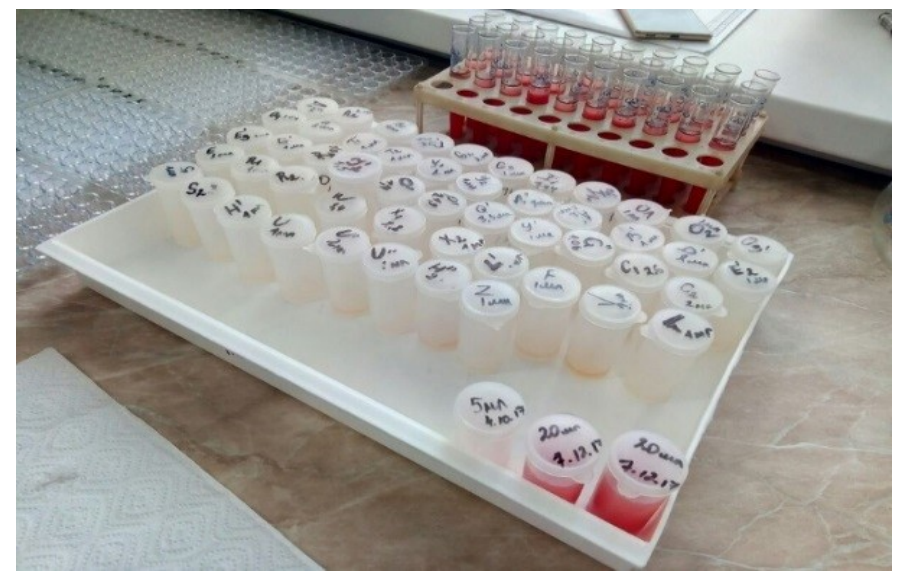

Fig. 1. Standard reagents.

\section{Results and discussion}

The very process of selection work on farms influences the formation of their gene pool and the determination of genotypes by blood groups, which will make it possible to divide the livestock according to their genetic differences. (Table 3).

The number of alleles, genetic systems and genotypes at each locus can be calculated by the characteristics of the blood groups of the livestock. 
For statistical analysis, the computer program Microsoft Office Excel was used, and the allele coefficient was calculated using the formula:

$\mathrm{q}=\mathrm{F} / \mathrm{n}$, where

$\mathrm{F}$ is the number of alleles in the studied livestock;

$\mathrm{n}$ is the total number of examined yaks.

Table 3. Coefficient of occurrence of blood group alleles in a herd "Selskie dary" pedigree breeding unit.

\begin{tabular}{|c|c|c|c|c|c|}
\hline Systems & Antigens & $\begin{array}{c}\text { Allele } \\
\text { frequency, } \%\end{array}$ & Systems & Antigens & $\begin{array}{c}\text { Allele } \\
\text { frequency, } \\
\%\end{array}$ \\
\hline \multirow[t]{2}{*}{ EAA } & $\mathrm{A}_{1}$ & 0.96 & \multirow[t]{8}{*}{ EAC } & $\overline{C_{1}}$ & 0.04 \\
\hline & $\mathrm{A}_{2}$ & 0.38 & & S. & 0.02 \\
\hline \multirow[t]{19}{*}{ EAB } & $\mathrm{G}_{2}$ & 0.16 & & $\mathrm{X}_{1}$ & 0.10 \\
\hline & $\mathrm{G}_{3}$ & 0.32 & & $\mathrm{X}_{2}$ & 0.23 \\
\hline & $\mathrm{I}_{1}$ & 0.64 & & $\mathrm{R}_{1}$ & \\
\hline & $\mathrm{I}_{2}$ & 0.40 & & $\mathrm{R}_{2}$ & 0.25 \\
\hline & $\mathrm{P}_{2}$ & 0.05 & & W & 0.05 \\
\hline & $\mathrm{O}_{3}$ & 0.80 & & L. & 0.08 \\
\hline & $\mathrm{O}_{4}$ & 0.21 & \multirow[t]{2}{*}{ EAF } & $\mathrm{F}$ & 0.82 \\
\hline & $\mathrm{A}_{2}^{\prime}$ & 0.58 & & $\mathrm{~V}$ & 0.02 \\
\hline & T. & 0.03 & \multirow[t]{8}{*}{ EAS } & $\mathrm{S}_{1}$ & 0.21 \\
\hline & V. & 0.06 & & $\mathrm{~S}_{2}$ & 0.14 \\
\hline & $\mathrm{D}^{\prime}$ & 0.28 & & U. & 0.21 \\
\hline & Q. & 0.32 & & U. & 0.54 \\
\hline & $\mathrm{Y}_{2}$ & 0.35 & & U. & 0.09 \\
\hline & $\mathrm{Y}_{2}^{\prime}$ & 0.41 & & H. & 0.59 \\
\hline & $\mathrm{E}_{3}^{\prime}$ & 0.24 & & $\mathrm{H}$. & 0.13 \\
\hline & $\mathrm{G}^{\prime}$ & 0.12 & & H. & 0.66 \\
\hline & $\mathrm{O}$. & 0.57 & EAZ & $\mathrm{Z}$ & 0.62 \\
\hline & $\mathrm{P}_{2}^{\prime}$ & 0.36 & EAL & L. & 0.06 \\
\hline & $\mathrm{T}_{1}$ & 0.03 & & & \\
\hline
\end{tabular}

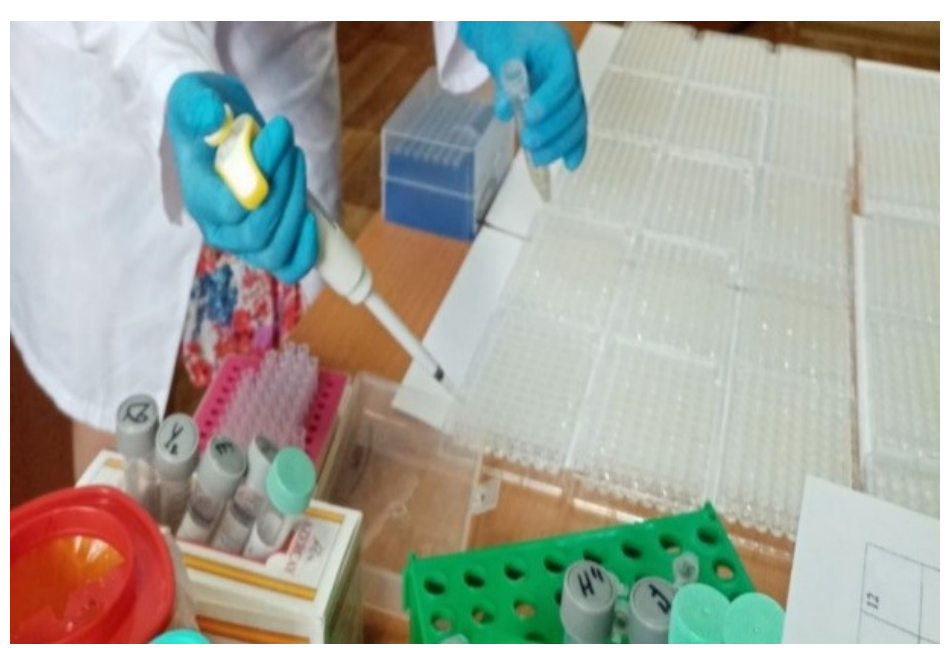

Fig. 2. Adding reagents to plates. 


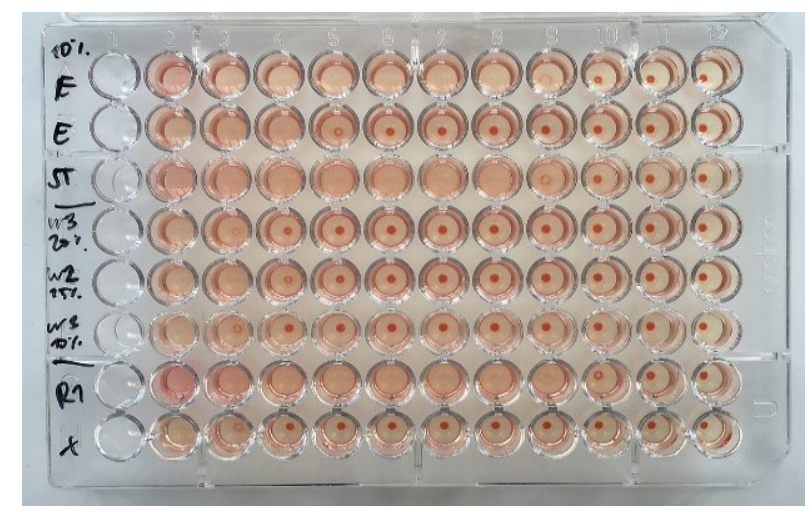

Fig. 3. Result of the hemolysis reaction.

The results of research on sarlik yaks at "Selskie dary" pedigree breeding unit show that in the systems:

- EAA - $\mathrm{A}_{1}$ and $\mathrm{A}_{2}$ antigens are detected, with the frequency of occurrence 0.38 and $0.96 \%$, respectively.

- EAB - 19 antigens are detected, with antigens $\mathrm{O}_{3}-0.80, \mathrm{I}_{1}-0.64, \mathrm{~A}_{2}^{\prime}-0.58, \mathrm{O}^{\prime}-0.57$, $\mathrm{I}_{1}-0.40$ being most frequent.

- EAC - 7 antigenic factors are detected, with $\mathrm{X}_{2}, \mathrm{R}_{2}, \mathrm{X}_{1}$ being most frequent -0.23 , $0.25,0.10$, respectively.

- EAS - H"- 0.66, H- 0.59, U'- 0.54 were detected with the maximum frequency.

- The antigens in the following systems were rare and not typical for sarlik yaks:

- EAB - B', $\mathrm{P}_{2}, \mathrm{~T}, \mathrm{~T}_{1}$, varied from 0.03 to $0.06 \%$;

- EAC - $\mathrm{C}^{\prime}, \mathrm{C} 1, \mathrm{~W}, \mathrm{~L}^{\prime}$, varied from 0.02 to 0.08 ( $\mathrm{R}_{1}$ was not detected at all);

- EAF - V antigen, $0.02 \%$;

- EAS - U" antigen, $0.09 \%$;

- EAL - L antigen, $0.06 \%$.

Thanks to the studies carried out, it was possible to establish the true origin of offspring by sires and dams (Table 4). From the presented biological material (blood) and family analysis, the reliability of the origin of replacement chicks was $99.0 \%$, and the discrepancy for both parents was $1.0 \%$.

Table 4. Overall reliability score of kinship.

\begin{tabular}{|c|c|c|c|c|c|c|c|c|c|c|}
\hline \multicolumn{3}{|c|}{ Samples investigated } & \multicolumn{5}{c|}{ Blood groups systems, \%: } \\
\cline { 4 - 10 } & \multicolumn{3}{|c|}{ EAA, EAB, EAC, EAF, EAS, EAZ, EAL } \\
\hline Total & Sires & $\begin{array}{c}\text { Dam } \\
\text { s }\end{array}$ & $\begin{array}{c}\text { B } \\
\text { ul } \\
\text { ls }\end{array}$ & $\begin{array}{c}\text { Heif } \\
\text { ers }\end{array}$ & $\begin{array}{c}\text { By } \\
\text { sire }\end{array}$ & $\begin{array}{c}\text { By } \\
\text { dam }\end{array}$ & $\begin{array}{c}\text { By } \\
\text { pare } \\
\text { nts }\end{array}$ & $\begin{array}{c}\text { By } \\
\text { sire }\end{array}$ & $\begin{array}{c}\text { By } \\
\text { dam }\end{array}$ & $\begin{array}{c}\text { By } \\
\text { pare } \\
\text { nts }\end{array}$ \\
\hline 231 & 37 & 97 & 3 & 61 & 0.0 & 0.0 & 1.0 & 99.0 & 99.0 & 99.0 \\
\hline
\end{tabular}

\section{Conclusion}

The possibility of determining the blood groups of an animal immediately after its birth suggests that it is possible to predict the future productivity of the offspring from them. As a 
result of the successful solution of this issue in the breeding work and the work of breeders, significant changes would follow.

Identification of different forms of the same gene located at loci allows in some cases to determine its genotype. Regardless of the current situation, this will give us the opportunity to select high-quality animals in selection and breeding work, which in turn will expand genetic variability and optimize the structure of the gene pool. The work carried out has shown that it is possible to improve the productive qualities of sarlik yaks by crossing animals with a rare blood group, and its combination with heterogeneous genetic markers made it possible to increase genetic variability in the livestock.

The results of the conducted research make it possible to preserve the gene pool of unique breeds of farm animals, which in turn preserves high-quality breeds of animals for crossing, and further maintains the level of the population while solving the assigned tasks.

This technique using 40 standard reagents from 7 genetic systems made it possible to determine the frequency of occurrence of blood group alleles in the herd. Also, the immunogenetic analysis of the blood of the investigated herd of the farm of the "Selskie dary" pedigree breeding unit showed that the majority of the livestock constituting the breeding base coincides with the intended offspring. Therefore, according to the studies carried out, an assessment of the reliability control of $99.0 \%$ was given, which is practically significant for the economy.

\section{References}

1. I. R. Giller, Tribal business and breeding biology of agricultural animals, 35 (1973)

2. I. Johanson, J. Rendel, O. Gravert, Genetics and breeding of farm animals (1970)

3. J. Matoushek, Blood group in cattle (1964)

4. D. N Koltsov, Yu. D. Romanov, M. E. Gontov, Achievement of Science and Technology, 57 (2011)

5. I. R. Giller, L. A. Oleinik, Immunogenetic similarity in cattle inbreeding, 51 (1978)

6. S. L. Gridina, V. F. Gridin, F. A. Sagitdinov, O. I. Leshonok, G. A. Romanenko, Agroindustrial complex of Russia, 857 (2016)

7. R. V. Manoilov, V. F. Gridin, Youth and science (2016), http://min.usaca.ru/

8. Rules of genetic examination of breeding material of cattle (2003) 